\title{
PENGARUH ZAT ADITIF PADA MORFOLOGI MEMBRAN HIBRID POLISULFON-LEMPUNG
}

\author{
Zaiyar \\ Dosen Kimia Sekolah Tinggi Teknologi Pekanbaru \\ Jl. KH. Ahmad Dahlan No. 88. Sukajadi. Pekanbaru \\ Email: zaiyar68@yahoo.co.id
}

\begin{abstract}
ABSTRAK
Morfologi membran hibrid polisulfon-lempung dengan zat aditif PEG dan lempung (PEL 1) berbeda dengan membran hibrid polisulfon-lempung dengan zat aditif lempung saja. Penggunaan 2 jenis zat aditif pada membran PEL 1 menyebabkan jumlah pori lebih banyak, ukuran pori lebih kecil dan distribusi pori lebih merata dibandingkan membran PL 1 yang hanya menggunakan zat aditif lempung saja. Zat aditif PEG pada membran PEL 1 berperanan pada pembentukan pori membran dengan cara meningkatkan koneksitas pori, sedangkan peranan lempung pada membran PEL 1 dan PL 1 melalui interkalasi visit host ke dalam polimer organik.
\end{abstract}

Kata kunci: Membran hibrid polisulfon-lempung, zat aditif, koneksitas pori visit host

\section{PENDAHULUAN}

Sintesis poliuretan pada dasarnya merupakan suatu aplikasi dari reaksi polimerisasi kondensasi. Reaksi polimerisasi kondensasi merupakan reaksi antara dua reaktan dengan dua gugus fungsi yang berbeda menghasilkan satu produk utama. Poliuretan yang terbentuk dari hasil reaksi kondensasi memiliki gugus uretan (-NHCOO) dalam unit ulangnya. Gugus uretan terbentuk sebagai hasil reaksi antara gugus isosianat (NCO-) dengan gugus hidroksil (-OH) (Rohaeti, 2004).

Membran merupakan lapisan tipis selektif bersifat semipermeabel yang berada diantara dua fase yaitu fase umpan (feed), dan fase hasil pemisahan (permeate). Pemisahan yang terjadi pada membran disebabkan membran mempunyai kemampuan untuk melewatkan komponen yang ukurannya lebih kecil dibandingkan pori membran karena perbedaan perbedaan tekanan, konsentrasi, atau perbedaan temperatur di antara kedua sisi membran (Mulder 1996).
Berdasarkan morfologinya, membran dibedakan atas membran simetris dan asimetris. Membran simetris memiliki struktur dan ukuran pori yang seragam dengan ketebalan 10-200 $\mu \mathrm{m}$. Membran asimetris merupakan membran yang memiliki struktur dan ukuran pori yang tidak seragam.

Membran hibrid adalah suatu membran yang dibuat dengan cara menambahkan bahan anorganik ke dalam matriks polimer (organik). Bahan dasar membran hibrid terdiri dari polimer dan zat aditif (matriks polimer). Penambahan bahan aditif pada bahan dasar membran bertujuan untuk meningkatkan atau memodifikasi sifat-sifat mekanik, kimia, dan fisik membran (Kim et al., 1989). Zat aditif dapat berupa molekul organik yaitu: polietilen glikol (PEG), sedangkan molekul anorganik yaitu: lempung,

Pada penelitian ini, dibuat 2 jenis membran hibrid polisulfon-lempung. Membran hibrid polisulfon-lempung pertama menggunakan zat aditif PEG dan lempung, yang kedua hanya menggunakan zat aditif 
lempung saja. Perbedaan jenis zat aditif ini bertujuan untuk meneliti pengaruh masingmasing zat aditif terhadap morfologi membran hibrid polisulfon-lempung yang dihasilkan. Morfologi membran ditentukan menggunakan alat Scanning Electron Microsocope (SEM)

Peranan PEG pada proses pembentukan pori membran dengan cara memperlambat proses pemisahan (demixing) antara pelarut dan non pelarut dalam bak koagulasi sehingga pemisahan kedua campuran tertunda (delayed demixing)), akibatnya memperlambat proses gelasi (Javiya et al., 2008).

Struktur lempung yang berlapis ini, menyebabkan mudahnya terjadinya penataan ruang dan muatan antar lapisan, sehingga berpotensi sebagai pengisi (host) pada membran hibrid melalui interkalasi polimer organik kedalam visit host lapisan anorganik lempung. Selain itu, kandungan silika $\left(\mathrm{SiO}_{2}\right)$ yang tinggi pada lempung asal desa Pallas (58\%), menyebabkan lempung ini berpotensi digunakan sebagai bahan aditif dalam pembuatan membran hibrid. Partikel silika akan berinteraksi kuat dengan matriks polimer menyebabkan membran hibrid yang dihasilkan memiliki kestabilan termal yang baik.

Scanning Electron Microsocope (SEM) merupakan alat yang digunakan untuk menentukan morfoladalah salah satu jenis mikroskop elektron yang menggunakan berkas elektron untuk menggambar profil permukaan bahan. Prinsip kerja SEM adalah menembakkan permukaan benda dengan berkas elektron berenergi tinggi seperti diilustrasikan pada Gambar 1.

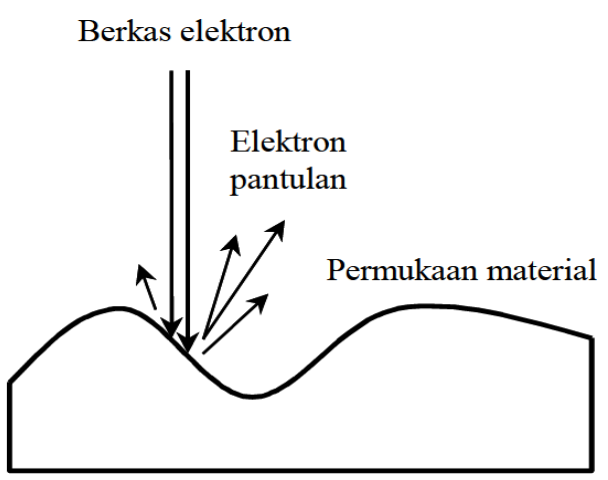

Gambar 1 Penembakan Permukaan Benda dengan Berkas Elektron Energi Tinggi (Sumber: Abdullah et al, 2008)

\section{METODOLOGI PENELITIAN}

\section{Alat-alat}

Scanning Electron Microscopy (SEM) model 7353, ayakan 200 mesh, pengaduk magnetik, batang stainless steel,

\section{Bahan-bahan}

Polisulfon UDEL P3500 (Solvay Advance Polymer $)$, lempung Desa Palas $\left(\mathrm{SiO}_{2}=58 \%\right)$, N,N-Dimetil asetamida (DMAc) (Merck), dekstran 400-500 kDa, dekstran 35-45 kDa, dekstran 8,5-11,5 kDa (average mol.Wt), polietilen glikol (PEG) 4000,

\section{Prosedur Kerja}

Pembuatan membran hibrid polisulfon-

\section{lempung}

Membran hibrid polisulfon-lempung yang dibuat terdiri dari 2 (dua) jenis membran. Membran pertama (PEL 1) menggunakan 2 jenis zat aditif yaitu lempung dan PEG, sedangkan membran kedua hanya menggunakan lemoung saja (PL 1) Membran pertama (PEL 1 dibuat dengan cara: melarutkan $18 \%$ polisulfon dalam $64 \%$ dimetil formamida (DMAc) dengan menggunakan zat aditif 9\% lempung, dan 9\% polietilen glikol.(PEG) Membran kedua (PL 1) dibuat dengan cara melarutkan $18 \%$ polisulfon dalam $64 \%$ dimetil formamida (DMAc) dengan menggunakan zat aditif $18 \%$ lempung. Proses pelarutan dilakukan pada temperatur kamar menggunakan pengaduk magnetik selama 15 jam sampai larutan 
homogen. Larutan ini, disebut larutan tuang polimer.

Larutan tuang polimer didiamkan selama 3 jam untuk menghilangkan gelembung udara yang terperangkap di dalam larutan sebelum dilakukan pencetakan (Tweddle et al., 1994). Larutan tuang polimer selanjutnya ditebar di atas plat kaca yang telah diolesi aseton lalu diratakan dengan batang stainless steel hingga terbentuk lapisan tipis dan dibiarkan selama 5 menit. Kemudian lapisan tipis pada pelat kaca direndam dalam bak koagulasi yang telah berisi campuran non pelarut 2-propanol-air perbandingan (1:1). Koagulasi dilakukan selama 5 menit, sehingga membran terkoagulasi.

\section{Karakterisasi morfologi membran} hibrid polisulfon-lempung

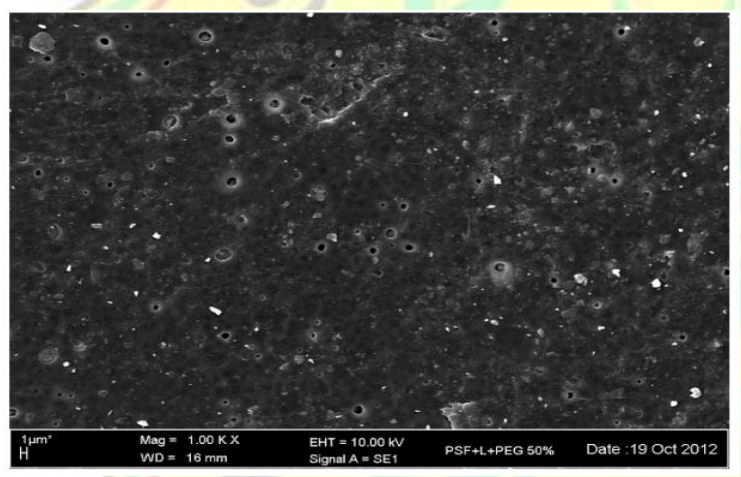

a

Gambar 2. Penampang Permukaan Membran PEL 1 (a). Perbesaran 1000 x b). Perbesaran 500x

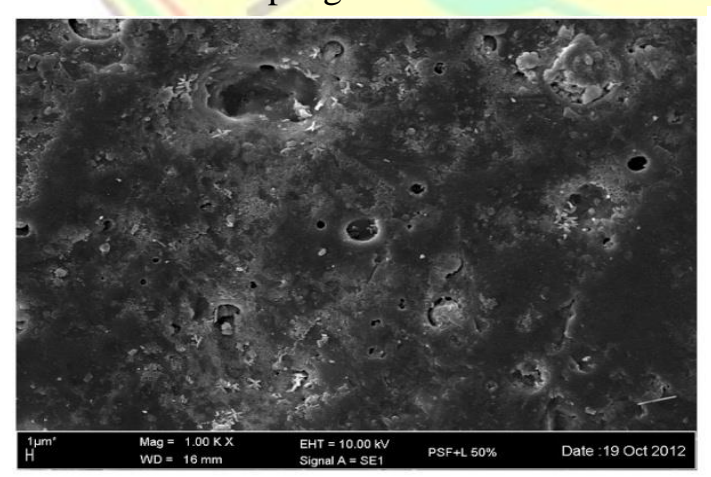

a
Karakterisasi morfologi membran hibrid polisulfon-lempung dilakukan menggunakan SEM. Pada analisis ini, membran direndam dalam nitrogen $\left(\mathrm{N}_{2}\right)$ cair dan selanjutnya dipotong menjadi 2 (dua) bagian menggunakan mikoton. Selanjutnya hasil pemotongan dilapisi dengan emas menggunakan ion sputter, kemudian diamati morfologi permukaan dan penampang lintang membran, dengan perbesaran 400 hingga 5.000x.

\section{HASIL DAN PEMBAHASAN}

Karakterisasi morfologi membran hibrid polisulfon-lempung PEL 1 dan PL 1 dilakukan menggunakan SEM. Hasil pengukurannya dapat ditunjukkan pada Gambar 2.

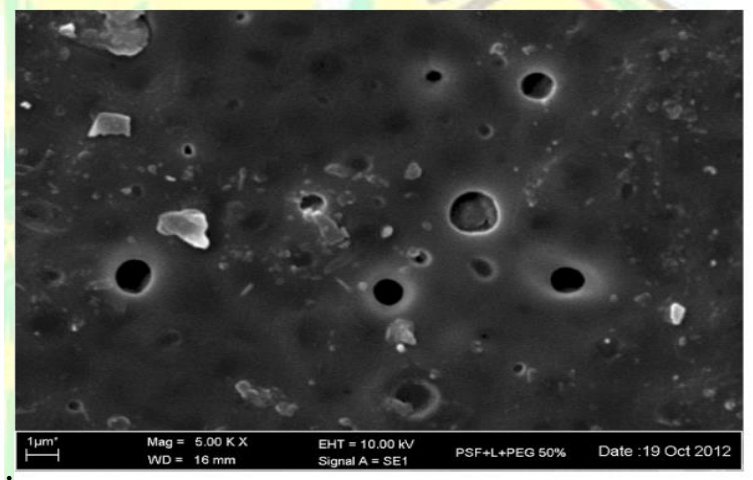

\section{b}

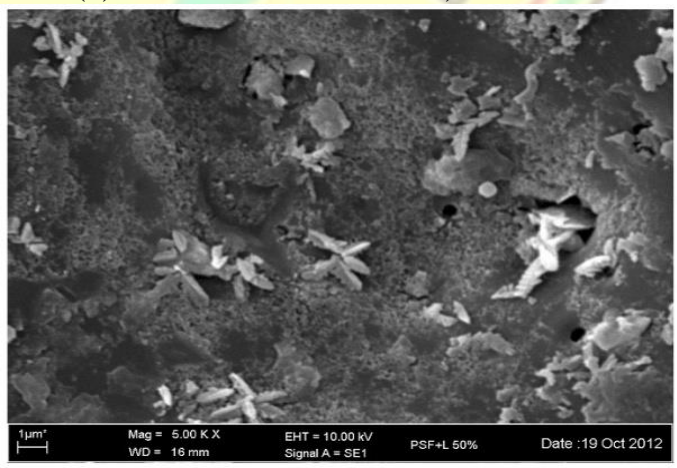

b

Gambar 3. Penampang Permukaan Membran PL 1, (a). Perbesaran 1000 x, (b). Perbesaran 500x 


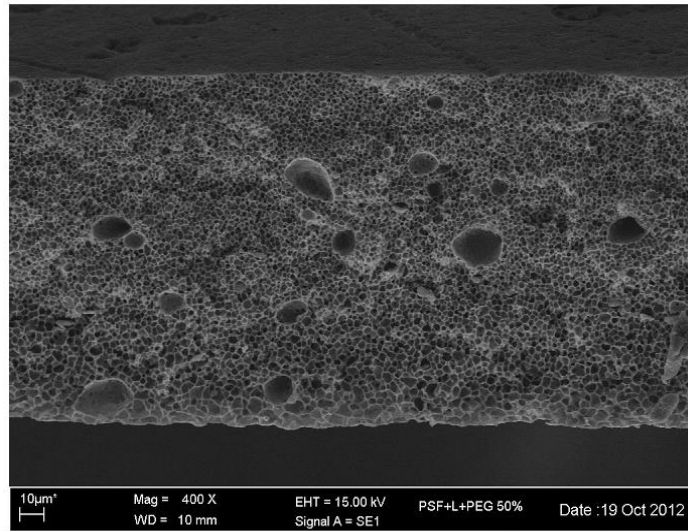

a

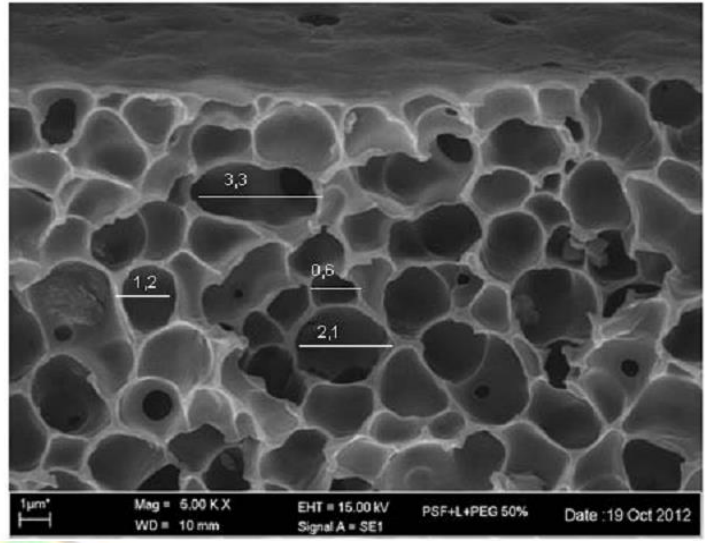

b

Gambar 4. Penampang Lintang Membran PEL 1 (a). Perbesaran 400 x, (b)Perbesaran 5000 x, Satuan diameter pori $(\mu \mathrm{m})$

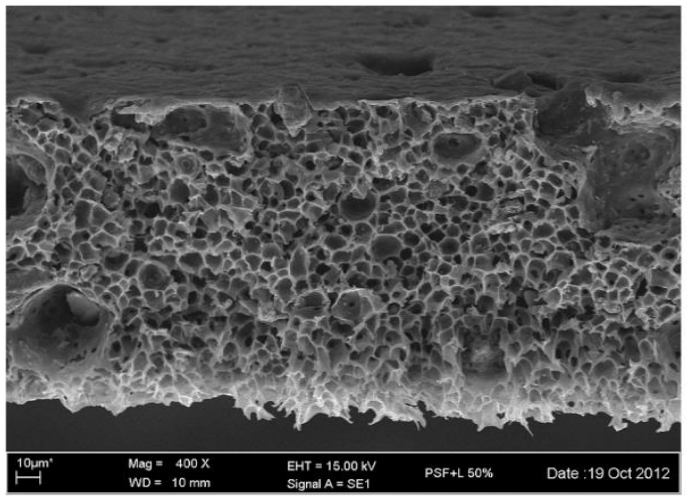

a

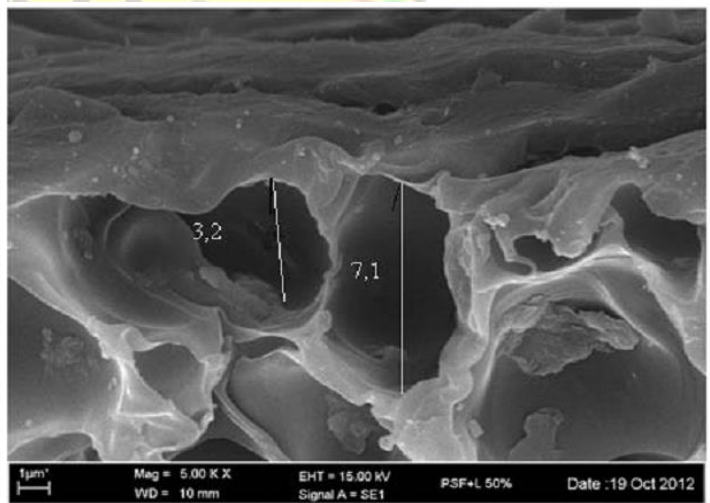

b

Gambar 5. Penampang Lintang Membran PL 1 (a). Perbesaran $400 \mathrm{x}$, (b). Perbesaran $5000 \mathrm{x}$, Satuan diameter pori $(\mu \mathrm{m})$

Berdasarkan Gambar 2-3 dapat dilihat bahwa permukaan membran hibrid polisulfon-lempung PEL 1 lebih halus dan lebih rata dibandingkan permukaan membran PL 1 (Tabel 1). Hal ini disebabkan, perbedaan komposisi zat aditif pada kedua jenis membran. Pencampuran antara polimer polisulfon dan lempung pada membran PEL 1 dan PL 1 menyebabkan terjadinya interaksi antara polisulfon dengan lempung secara kimia melalui gugus sulfon dan alkoksi pada polisulfon dengan silika atau $\mathrm{OH}$ pada lempung membentuk hibrid. Intensitas silika yang tinggi pada lempung yang berasal dari desa Palas (Nadarlis, 2012), menyebabkan ikatan hidrogennya juga tinggi, sehingga lempung masuk ke dalam jaringan matriks polisulfon membentuk membran hibrid. Hasil ini sesuai dengan penelitian Anadao et al., (2010), yang menggunakan montmorillonit sebagai komponen membran nano komposit polisulfon.

Tabel 1. Ukuran, Jumlah dan Distribusi Pori Membran PEL 1 dan PL 1

\begin{tabular}{ccc}
\hline Parameter & Membran PEL 1 & Membran PL 1 \\
\hline Ukuran Pori & $0,6-3,3 \mu \mathrm{m}$ & $3,2-7,1 \mu \mathrm{m}$ \\
Jumlah Pori & +++++ & ++ \\
Distribusi Pori & Merata & Kurang Merata \\
Permukaan & Lebih Halus & Kasar \\
\hline
\end{tabular}

Keterangan: ++++ = Jumlah pori banyak dan ++ = Jumlah pori sedikit 
Pada permukaan membran PEL 1 dan PL 1, juga dapat dilihat adanya lapisan tipis selektif yang berperanan pada proses pemisahan menggunakan membran. Lapisan selektif pada membran PEL 1 lebih rapat dibandingkan membran PL 1. PEG dan lempung yang terdapat pada membran PEL 1 dapat larut secara baik dalam pelarut DMAc dan bercampur sempurna dengan polimer polisulfon. Zat aditif PEG dan lempung mampu meningkatkan konektisitas ikatan pada matriks polimer membran membentuk lapisan selektif yang menyatu dengan baik. Hasil ini senada dengan Meretsa (2012), yang melaporkan bahwa membran hibrid polisulfon-lempung mempunyai lapisan selektif lebih rapat dibandingkan membran polisulfon (tanpa zat aditif lempung dan PEG).

Berdasarkan analisis permukaan membran PEL 1 dan PL 1, dapat dilihat adanya tumpukan partikel kasar yang kemungkinan berasal dari lempung. Hal ini berarti, lempung tidak tersebar merata pada matriks polimer kedua jenis membran dan kemungkinan terjadi pada saat menuangkan larutan homogen matriks polimer pada permukaan kaca (proses pencetakan) Ukuran lempung yang digunakan hanya lolos ayakan 200 mesh merupakan faktor penyebabnya. Hasil ini berbeda dengan Defontaine et al., (2009) yang menggunakan lempung berukuran nano dalam pembuatan membran poli dimetil siloksan (PDMS), yang menunjukkan morfologi membran PMDS tanpa adanya tumpukan partikel lempung pada permukan membran.

Berdasarkan morfologi penampang lintang membran PEL 1 dan PL 1 pada Gambar 4-5 dan Tabel 1 dapat dilihat adanya perbedaan ukuran pori, jumlah pori dan distribusi pori pada kedua membran hibrid polisulfon-lempung PEL 1 dan PL 1. Fungsi zat aditif PEG sebagai porogen menyebabkan membran PEL 1 mempunyai jumlah pori lebih banyak dibandingkan membran PL 1. Menurut Javiya et al., (2008), selain sebagai porogen, PEG juga berfungsi menjaga ketahanan membran terhadap faktor eksternal. Zat aditif PEG mengisi matriks polimer secara sempurna sehingga menghasilkan membran dengan distribusi pori lebih merata. Hal ini disebabkan dalam proses difusi pembentukan membran, zat aditif PEG bersama dengan pelarut akan larut ke dalam non-pelarut 2-propanol-air dengan meninggalkan rongga atau pori pada membran

Dalam proses inversi fase pembentukan membran, cikal bakal pori (nascent pores) akan terus tumbuh, jika pelarut non pelarut 2popanol-air secara terus menerus terdifusi ke dalam larutan tuang, akan mempengaruhi pelarut yang berada di sekitar cikal bakal pori sehingga terdifusi keluar. Difusi dari pelarut (DMAc) ini, akan mengakibatkan konsentrasi polimer meningkat sehingga pertumbuhan ukuran pori akan berhenti (Young et al., 1996). Difusi non pelarut (2-propanol-air) kedalam larutan tuang yang diiringi oleh difusi pelarut (DMAc) keluar larutan tuang mengakibatkan pertumbuhan pori berhenti sehingga ukuran pori menjadi relatif kecil.

Ukuran pori membran PL 1 yang lebih besar dibandingkan membran PEL 1 (Gambar 4 dan Tabel 1) disebabkan lebih mudahnya difusi non pelarut 2-propanol-air kedalam matriks membran PL 1 menggantikan pelarut DMAc. Partikel silika yang terdapat pada lempung dapat berinteraksi secara kuat dengan matriks polimer karena tidak adanya zat aditif lain (hanya lempung) sehingga menghasilkan membran hibrid polisulfonlempung dengan ukuran pori besar pada sublapisan. Dengan demikian dapat dinyatakan bahwa zat aditif PEG akan meningkatkan jumlah dan distribusi pori, 
sedangkan zat aditif lempung memperbesar ukuran pori.

Berdasarkan morfologi permukaan dan penampang lintangnya, membran PEL 1 dan PL1 termasuk jenis membran asimetris karena ukuran porinya yang berbeda (Scott \& Hughes, 1995). Ukuran pori membran PEL 1 berada pada kisaran 0,6-3,3 $\mu \mathrm{m}$ dan membran mempunyai ukuran pori PL1 3,2- 7,1 $\mu \mathrm{m}$ yang menunjukkan kedua membran ini, termasuk jenis membran mikro filtrasi.

Perbedaan jenis non pelarut dan variasi non pelarut mempengaruhi pembentukan pori membran (Radiman, 2007). Non pelarut 2propanol-air mempunyai rasio difusi lebih rendah dari non pelarut air, akibatnya pencampuran antara non pelarut 2-propanolair dan pelarut DMAC berlangsung lambat. Waktu induksi yang diperlukan 2-propanolair ke dalam larutan tuang untuk membentuk inti semakin lama dan pemisahan fase caircair juga berlangsung lambat karena membran mempunyai waktu tunda untuk membentuk pori.

\section{KESIMPULAN}

Berdasarkan hasil penelitian dapat disilmpulkan bahwa Zat aditif mempengaruhi pembentukan pori pada membarn hibrid polisulfon-lempung. Penggunaan 2 jenis zat aditif yaitu organik (PEG) dan an organik (lempung) pada membran hibrid polisulfon PEL 1 dan yang hanya menggunakan 1 jenis zat aditif an organik (lempung) pada membran PL 1 menyebabkan terjadinya perbedaan jumlah pori, ukuran pori dan distribusi pori pada kedua jenis membrane

\section{DAFTAR PUSTAKA}

Abdullah, M., \& Khairurrijal., 2008, Review: Karakterisasi Nanomaterial. Jurnal Nanosains \& Nanoteknologi 2 (1).

Anadao, P, Sato, L.F. Wiebeck, H \& Diaz, F.R.V., 2010, Montmorillonite as
Component of Polysulfone

Nanocomposite Membranes, Applied Clay Science 48: 127-132.

Defontaine, G. Barichard,A. Letaief,S. Feng,C.Matsuura, T \& Detellier,C., 2009, Nanoporous Polymer-Clay Hybrid Membranes For Gas Separation, J.Colloid 15 (2): 622-627.

Javiya, S. Yogesh, Gupta, S. Singh, K \& Bhattacharya, A., 2008, Porometry Studies of The Polysulfone Membranes on Addition of Poly(Ethylene Glycol) in Gelation Bath During Preparation, J.Mex.Chem. Soc 52 (2): 140-144

Kim, H.J. Tyagi, R.K. Fouda, A.E \& Jonasson K., 1996, The Kinetic Study for Asymmetric Membrane Formation Via Phase-Inversion Process, Journal of Applied Polymer Science, 62: 621-629

Mulder, M., 1996, Basic Principles of Membrane Technology. Second edition. Kluwer Academic Publishers, Dordrecht.

Nadarlis., 2012, Identifikasi dan Karakterisasi Lempung Alam Desa Palas Kecamatan Tampan dan Desa Talanai Teratak Buluh Kecamatan Siak Hulu, Skripsi Jurusan Kimia FMIPA UR, Pekanbaru.

Radiman, C.L \& Eka I., 2007, Pengaruh Jenis dan Temperatur Koagulan Terhadap Morfologi dan Karakteristik Membran Sellulosa Asetat, Makara Sains 11 (2).

Scott, K \& Hughes R., 1996, Industrial Membrane Separation Technology. Chapman \& Hall, New York.

Tweddle, T.A. Striez C.N \& Kutowy O.,1994, Laboratory Workshop, Membrane Fabrication and Membrane Testing, CIDA Course, Canada

Young, T. H \& Leo, W.C.,1996, Pore Formation Mechanism of Membranes from Phase Inversion Process, Desalination 103: 233-247. 